\title{
FILM NARRATIVE IN CONTEMPORARY LITERATURE: AN ARGENTINIAN EXAMPLE*
}

\section{Cristine Fickelscherer Mattos* *}

\begin{abstract}
This article investigates the presence of film language in contemporary fiction through the example of two novels of the Argentinian writer Tomás Eloy Martínez: La novela de Perón (The Perón Novel - 1985) and Santa Evita (Saint Evita - 1995). Unlike the major work about adaptation it takes the intermedial dialogue in reverse - from film to book - to focus on media configurations and their specific intermedial qualities. It also discusses the historic relations between literature and cinema to consider the way this Hispanic literary production incorporates specific cinematic devices.
\end{abstract}

Keywords: Intermediality. Tomás Eloy Martinez. Montage.

[...] esos arreglos son moneda corriente en el cine. Un salto de montaje o un fundido a negro bastan para inventar otro pasado. En el cine no hay historia, no hay memoria. Todo es vida contemporánea, presente puro. Lo único verdadero es la conciencia del espectador

(MARTÍNEZ, 1995, p. 47)

\section{INTRODUCTION}

"F

rom the last decade of the $20^{\text {th }}$ century onwards, an increasing number of studies linking literature and cinema have been produced, especially concerning adaptations of books into film. Although an interest in the connections between the two fields had first arisen in the early $20^{\text {th }}$ century, for instance in the work of the theorist Béla Balázs ${ }^{2}$, a theoretical approach

* The present article consists of a reviewed and expanded paper, presented in $21^{\text {th }}$ World Congress of the International Comparative Literature Association, at the University of Vienna, Austria, in July, 2016.

** Universidade Presbiteriana Mackenzie (UPM) - São Paulo - SP - Brasil. E-mail: cristine.mattos@mackenzie.br

1 [...] these arrangements are currency in the cinema context. A leap in montage or a fade-in are enough to have another past invented. In cinema there is no history, there is no memory. Everything is contemporary life, pure present. The only real thing is the viewer's consciousness."

2 Béla Balázs (2011) wrote about adaptation in his "Sketches for a Theory of Film", inside Visible Man (1924). 
based on semiology and intertextuality only materialized a several decades later. Crucial conclusions through analyses and contrast of narrative, textuality, perception and comprehension processes were then reached. The comparative considerations, throughout the history of a book /film dialogue, had their point of departure and prestige in literature. They mostly focused on the content rather than the medium and very often just observed its transposition from page to screen.

This paper proposes a comparative analysis of this dialogue in reverse: focusing essentially on the medium, although still watching out for the content and having cinema as a point of departure to investigate the presence of film language in contemporary fiction. It will investigate two novels of the Argentinian writer Tomás Eloy Martínez: La novela de Perón (The Peron Novel - 1985) and Santa Evita (Saint Evita - 1995). It aims to compare the different ways each novel embodies the film language procedures and raises questions about the possible contextual reasons for the found differences.

First, some theoretical background will be explained for the sake of providing the necessary conceptual framework for the analysis. Secondly, some analytical statements will be presented and will also include historical contextual considerations. Finally, the analytical work will be linked to the contextual observations regarding contemporary literature.

\section{THEORETICAL BACKGROUND}

The reason to focus on the medium, as here proposed, was rooted in the conviction that media determinations over messages are an unavoidable and essential building block for any results in communication. According to Marshall McLuhan (1979), a medium is a technological extension of human capabilities and it creates an environment that works as text with its own grammar, revealing a language. Most of McLuhan's efforts, unfortunately not always understood, seem to highlight the need of content considerations to be taken further by more wide-ranging studies that would focus on the medium as a whole system with its own language. Moreover, he also argued that the medium is capable of not only generating new elements but also reshaping culture (MCLUHAN, 1979).

At the same time - the mid-sixties -, several inter-arts critical studies (some looking at the above mentioned issues in a less theoretical way) also emerged and highlighted the need for more analytical attention to be devoted to media as a whole. These studies generated a considerable amount of critical issues taken under the name of intermedia. Over the years, the term intermedia became synonym to interdisciplinary practice in Humanities. Given the vast range of possible crossed relations between media and the fact that many studies have shown a variety of heterogeneous critical uses of intermedia, they have been bundled together under the term intermediality.

In order to solve conceptual misunderstandings, due to different media and because of unequal functions the intermedial element may use or have, Irina Rajewsky (2010) established some substantial theoretical distinctions. According to her, as a crossing borders way of work between media (RAJEWSKY, 2010), intermedial products can be focused from three different approaches: a synchronic/diachronic perspective inside an intermedial history of media; a 
fundamental condition of the creative process versus a critical category for concrete analysis and a phenomenon taken under some specific epistemological approach with its corresponding objectives and conceptions (RAJEWSKY, 2005).

Besides that, for literary study purposes like this one, Rajewsky also defined three different kinds of intermediality: as medial transposition (here a medium product substratum comes into being in another medium - like adaptations do); as media combination (referring to phenomena in which there are multi or mixed media making a single work or event) and as intermedial references (here the medium product uses its own medium-specific means, either to refer to a specific, individual work produced in another medium or to refer to some other specific medial system/subsystem) (RAJEWSKY, 2005, p. 50-53).

For the film language investigation in the two Argentinian novels by Tomás Eloy Martinez, as aimed here, this analytical work will use the third approach, in other words, some specific epistemological point-of-view in literary studies. It will also consider, however, some synchronic and diachronic aspects involved in the production of the texts, as well as some observations about the reception process for understanding them. A further conceptual instrumentation of analysis, concerning this specific area, will make use of the third kind of intermediality, taking film language as an intermedial reference system for the writing and the reading of the two novels.

As mentioned before, a lot of comparative researches focusing on literature turned into film or literary language used in films have been produced but considerably less studies, if set side by side, have done the opposite path. However, we can find some tradition in this way. Among many possible aspects of film language that may be transposed or appear in literature, one of the most emphasized ones in comparative works concerns montage devices ${ }^{3}$. According to several theorists, being montage the main element to characterize film language specificity, it is natural to have montage devices in the front stage. Nevertheless, there is no conceptual agreement about the definition of montage, neither as a film language component nor as a narrative praxis in literature. Hence, there is a puzzlement outcome in any research regarding the settlement of patterns. Due to the restricted possibilities of developing this issue in this paper, some simple delimitation will be made for a conceptual instrumentation of montage in the analysis, especially as this paper does not aim to solve this definition dilemma.

A general survey easily identifies two main modes of montage in cinema: the American one and the Soviet one. In the first case, it refers mainly to a way of connecting separated images to reach temporal and spatial continuity. In the second one, it means a strategy to suggest symbolical messages through a sequence formed by a combination of contrasting images. For practical proposes, this paper will adopt Amiel's (2010) terminology to refer to these two types of montage: narrative montage, for the American mode, and discursive montage, for the Soviet one ${ }^{4}$. Although it may seem that the narrative montage is more

3 Montage devices will be used here as a general procedure for the connections between the shots because they help to explain some conceptual and analytical intermedial differences. Montage will be taken here both for continuity editing and non-narrative editing (albeit only the last one is more commonly referred as "montage" in English, as explained by BORDWELL; THOMPSON, 2014, p. 404-407).

4 As the notions of continuity/discontinuity, commonly used in English, are not exclusive of film editing procedures, this paper uses the French terminology to distinguish the film montage modes. Amiel explains about two film technical procedures or two film montage logics: decoupage and collage. The first one focuses on continuity and the last one stresses discontinuity (placing side by side non usual elements without connecting their contents, in other to change our perception of them). According to Amiel, 
concerned with "connecting" than the discursive montage, because of the conflict between images, both modes are ultimately committed to the addition results of the single visual parts ${ }^{5}$.

The above mentioned distinctions apart, any survey of studies about film language in literature will not find clear montage parameters. A variety of expressions try to handle the conceptual lack of definition: "film writing", "montage novel", "cinematic novel", literary "pen-camera", "novelizations", "literary cubism", among others. Following the great montage schools, many critical works differ from each other because of their alternated stress in continuity/ discontinuity as a signal of film montage presence in literary texts. The analytical approach here stems from the belief that the blurry conceptual situation of comparative "film to novel" studies is a result of wrong theoretical perspectives or, further than that, it might be the result of the absence of a proper theoretical framework that takes into account the issues of the two different media. Media specific aspects have been ignored in most intermedial comparative studies and especially in film to book researches.

To insert media considerations in comparative literary analysis in this paper, montage will be taken as a system presence in the literary texts here assigned, i.e. as a cinematic intermedial reference. Unlike most analytical studies, the contributions of both schools of montage will be considered and their unequal influence in the analyzed novels will be measured.

Some frequent unattended questions must be answered first: the presence of montage in literature always mean a film montage reference? What is needed to claim that a novel contains montage references? Beyond the evident need for a minimum number of occurrences, to be a montage referencing work, montage procedures must be an inner component, part of the deep structure and must be integrated to the meaning production process of a literary text.

Some discussion about film presence in literature would fade out only giving up the isolated or accidental occurrence of montage procedures in literature. If we look carefully, it is possible to find a "cut-and-bound" passage as old as we can seek. Sergei Eisenstein, one of the most important montage theorists, found examples of cinematic montage principles in $19^{\text {th }}$ century literary works ${ }^{6}$. However, in his examples montage appears as an occasional occurrence, and not as a system resource.

Yet the existence of a systematic montage in an even older example as Laurence Sterne's narrative Tristram Shandy in the $18^{\text {th }}$ century could undermine any heuristic proposition. His unconventional time scheme of fractured narrative sequence and associated ideas allowing surprising juxtapositions between events seems to be a montage system presence in a time of no cinematic references. Therefore, montage devices, when conceived just as a continuity/discontinuity opposition, cannot be taken as a cinematic expedient, but only as a narrative one, that cinema had to find a way to express through sequential images.

these two logics have combined presence in three possible types of montage: the narrative montage, the discursive montage and the montage by correspondence. The ways of using mostly decoupage logics create the narrative montage. The ways of using mostly collage logics create discursive montage or the montage by correspondence. Due to the restricted extension of this paper, the analysis will not observe the third one in Martínez novels (AMIEL, 2010, p. 19-22).

5 Discursive montage as practiced in the Nouvelle Vague is easily seen as an expression of dissociation aesthetics, with only conflict function. However, the intended metaphoric effect could be considered another expression of a main junction purpose and not just of a dispersive one, in terms of the communicated signification.

6 Notes about Flaubert's work in Eisenstein (1977, p. 12-13). 
Using this opposition as a criterion for understanding montage will not leave us much to say about its transposition to literature as an intermedial reference. There is a need to look for cinematic ways of "cutting and bounding" in literary narrative as an authentic cinematic system with its own cinematic language, even if expressed in literary ways.

By the eighties, when Tomás Eloy Martinez wrote The Perón Novel, the relationship between cinema and literature had already taken many configurations, and so have the comments about the presence of cinematic montage in literary works. The avant-garde fragmentation had met, in the 20s, synchronic echoes in the film language development that was creating expression procedures closer to literary narrative through the new found montage devices ${ }^{7}$. After the apogee of artistic and poetic vanguard, fragmentation reached novel and so did montage devices as system references, introducing new fracturing ways to narrative sequence and intensifying the frequency of time and spatial changes ${ }^{8}$.

It should be noted that cinematic montage techniques were at first developed by the American school, mainly to preserve the narrative continuum in spite of the fractured nature of its language. Because of media differences, literature took montage shattered composition as a reference instead of its original binding purpose. Many critical studies have been made about these early $20^{\text {th }}$ century novels and some have pointed out the maintenance of a master logic structure orchestrating the atom system dynamics (often through allegory), despite fragmentation. At any rate, in these novels, there are more intermedial references to a narrative montage system than to a discursive one, since we cannot find significant changes in its points of view or in the implied constellation of values assigned by the fragments.

As a medium, cinema has reshaped culture and has educated the viewer's gaze to wipe out image fractures in favor of a continuum perception. The first impact of film language had passed away and a more radical rupture could be tested in literature. By the middle of the $20^{\text {th }}$ century second half a true decentered novel was born, certainly not by coincidence during the rise of post-structuralism assessments. In this case, the presence of different world perspectives with no closing solution makes it similar to a discursive montage system and signs a new cinematic intermedial reference. Nevertheless, the narrative montage system may then still be found, although now with a different function.

\section{The Argentinian context}

In the Argentinian context, after some early $20^{\text {th }}$ century vanguard experimentation by the ultraismo and in the singular work of Robert Arlt, it is possible to identify a narrative montage system - i. e. stressing fragmentation, although building a metaphorical or an allegorical master logic - in novels published around the sixties, like Cortázar's Hopscotch (1963), the early work of Manuel Puig, Betrayed by Rita Hayworth (1968), Saer's Scars (1969) and Tomás Eloy Martínez's first novel, Sacred (1969). Some years later, Puig and Martínez took a step further

7 Working with Porter contributions heritage, Griffith had established in the 20 s new film cutting devices, out of the cuttings of the illusionist theatre from Méliès.

8 To Emir Rodríguez Monegal (1972), despite the general vanguards influence, James Joyce fragmentation in Ulysses - according to him, a novel with a binary structure of significations - had a particular role to the Latin-American novels development in the sixties, working as a model for many novelists production like Cortazar's Hopscotch, Lezama Lima's Paradiso, Carlos Fuentes' Cambio de Piel and Cabrera Infante's Tres tristes Tigres (MONEGAL, 1972, p. 88-89). 
and began producing decentered novels such as Kiss of the Spider Woman (1976) and The Perón Novel (1985). As decentered texts, Juan José Saer's Nobody Nothing Never (1980) and Piglia's Artificial Respiration (1980) can also be mentioned.

In these last four novels, the reference to a discursive montage system can be detected together with the reference to a narrative one. The eighties novels opened their signification by means of point of view proliferation, with no master guideline. However, they still use narrative montage devices, but now in the original way, i.e. for the sake of a necessary narrative cohesion, so that the understanding is kept. Thus, unlike vanguard, narrative montage references stress no fragmentation in decentered novels. The vanguard fractured proposition, trying to avoid and destruct the past in order to innovate, almost reached the silence, as stated by Umberto Eco (1985, p. 56-57). The fictional answer to the modernist creative impasse was a postmodernist novel discursively opened by the presence of various points of view, but also made by resourceful conventional narrative bindings. Both scattering and stringing together procedures come to be a cinematic intermedial reference in contemporary novels, as shall be seen through the example of Tomás Eloy Martinez.

\section{An Argentinian film narrative}

The closeness of this Argentinian writer to cinema is very easy to notice. In 1961, he published a critical book on the works of two Argentinian film directors: Fernando Ayala and Leopoldo Torre Nilsson. He also wrote screenplays in co-authorship throughout the sixties and the seventies. In his novels, characters often meet cinema subjects. In Santa Evita, the author-character writes an outline of a screenplay which can be read by the reader of the novel. Besides that, cinema has a great presence in Argentinian cultural history, with straight connection to literature.

Working as a journalist for many years, Tomás Eloy Martinez had very close experiences with politics. The seeming main plot of The Perón Novel centers on Peron's return to Argentina (after 18 years in exile) and on the Ezeiza's airport massacre unleashed by his arrival. Although it resembles a factual plot, founded in a historical episode, no objectivity can be found and the events themselves are hard to be established. The historical moment is narrated through a kaleidoscopic view, made of many narrative branches telling the story of numerous characters synchronic and diachronically involved with it. The blurred fictional reality is extra textually related to a confusing journalistic experience of Martínez in a real life interview with Perón in Madrid while he was still banished from his country. In the novel there is a journalist character named Zamora which resembles the author, but the reader is made to feel confused when a new journalist character named precisely Tomás Eloy Martinez appears before the end of it. Each of the narrative branches carries its own point of view about Perón, the historical events and their truth. Perón himself features a character lost about his identity within the political manipulations.

Such a novelistic world is the result of a discursive montage work. Contrastive images have their imagistic value changed by the contiguity relations, in order to disclose unclear meanings. The variety of perspectives to understand and to act inside the assigned peronist moment brings to light its paradoxical 
constitution and suggests the clashed reasons for the Ezeiza's tragedy. However, as pointed before, to attest the presence of cinematic intermedial references some procedures must be identified.

A frequent way of doing discursive montage in literature is to change the frame of reference, focusing on an inner specific subject. It may be done through nondiegetic inserts or by simply stressing some diegetic unnoticed event, using a drastic framing transition, usually to close-up or pointing out some detail through a transition to a extreme close-up frame ${ }^{9}$. The meaning relation between the unequal images within the frames, a symbolic one, will have to be interpreted by the message receptor.

In The Perón novel, a good example of this kind of montage can be seen in the transition of chapter seven to chapter eight. The first one ends with an abstract mentioning of time: "And he felt that he too was entering history. That it was all a new time annunciation or an epiphany. And Arcangelo Gobbi would ever read his name in the pages of that time" (MARTÍNEZ, 1985, p. 170-171) ${ }^{10}$. The other one begins with a reference to a clock:

The pendulum clock of Ezeiza's international hotel hasn't stroke nine o'clock yet. God knows if it will ever do so, cousin Julio thinks, sitting at the breakfast table with wet trousers and a photo of Tomas Hilario Perón, his father, in his jacket pocket (MARTÍNEZ, 1985, p. 47).

The relations between the two different "times" follows the system relation between frames in discursive montage - an abstract one and a materialized one - and will have to be worked out by the reader. The abstract reference to time had changed to a close-up one with the mention of the pendulum clock.

Further on, in the same chapter, a close-up in the same hotel clock will be the montage excuse to a non-diegetic insert of another clock settled in another time and space: the clock of their grandmother. But the process of association does not stop and a little statue placed next to the hotel clock leads to another close-up insertion of a different little statue from the Church of Merces. These few examples show how the discursive montage works as a cinematic intermedial reference inside the literary and novelistic language. It's worth stressing again that this montage resources point out a contrast within a continuity process or, in other words, there is a contrast due to the continuity process going on. As already pointed out, film montage is committed to the addition results, even when stressing contrast or conflict in discursive montage. Unlike the vanguard literary tendency, in The Perón Novel an addition effect is reached though contrastive transitions.

As remarked before, the narrative montage can also be found in The Perón Novel. It is needed now to maintain the narrative thread: the shattered fictional world encloses many binding points, even though not immediately recognizable by the reader. The mentioned passage about cousin's Julio wet trousers has no contextual explanation and can only be understood in connection with the content of chapter three. In this case, in spite of the fact that time lapses, flashba-

9 Bordwell's examples for the nondiegetic inserts as a significant violation of continuity that produces a metaphorical or symbolic relation between the shots: in Fury, Fritz Lang cuts from housewives gossiping to shots of clucking hens; in Eisenstein's Strike, the massacre of workers is intercut with the slaughter of a bull (BORDWELL; THOMPSON, 2014, p. 396). Amiel's examples for drastic framing transitions in discursive montage: in Eisenstein's Battleship Potemkin, the close-up frames in soldiers guns and boots to mean the sailors menaced gaze (AMIEL, 2010, p. 67) and the extreme close-up frame in the dropping needle tip in Kubrick's Pulp Fiction (AMIEL, 2010, p. 70).

10 All quotations had their translations to English specially produced for this paper, based on the original in Spanish. 
cks and simultaneous narratives are usual literary devices, the way it is done here acknowledges a cinematic reference.

In narrative montage, one of the most important devices is the general match cut, whose function is to create continuity. A match cut usually employs image repetition. It is important to say that general repetition used as narrative connection is very common in literature. Film reference can be detected in literature because of the visual way of doing it. Image repetition is a frequent junction mode of the split novel here analyzed, e.g. by the intermittent appearance of the same airport clock along two chapters. A clear cinematic reference about it can be seen in most passages. For example, after a contextual scene, functioning as an establishing shot, a new element is inserted in the same scene, before a cut to another space or time. Later in the novel, another narrative branch refers to the same previously inserted element to make a binding point. That's the case of uncle's Julio in chapter three: gathered with other characters from Peron's past in Ezeiza airport (establishing shot), having his trousers wet because of physiological dysfunctions (stressed element) and shortly after sinking into memories. Later, in chapter eight, the reader comes across a reference to cousin Julio's wet trousers again as remarked before. This schematic dynamics will follow the same performance all over the novel, repeating previous elements strategically inserted to make narrative connections.

Another usual way of achieving narrative continuity in films is through sound transitions, e.g. by having the sound for the next scene beginning at the end of the preceding scene to link them. In chapter eight, a sound transition is used just as a film match cut. Uncle Julio, after pointing out that character Maria Amelia is listening to the radio and cannot hear him, sinks into memories once more. The story of remembered episodes is further cut by the sound of Maria Amelia's radio opera, before revealing to the reader that the narrative is back to the scene where both characters are sitting together. Important to notice is that these examples are about film language reference within literature language, i.e. a literary mode of expressing itself "as if" it was a film.

The second novel to be commented on here is Saint Evita. It was written ten years after The Peron Novel, in 1995. It is natural to think that literary references to film language at that time had changed since cinema itself had gone through several changes. New montage devices, above all, had been reshaping culture, educating the eye of viewers, enabling them to understand easily current crazy image sequences. This leads to the heuristic proposition of having in film language great driving forces of innovation in contemporary literature. This happens especially in a context of increasing presence of audiovisual products by the turn of the century and, remarkably in Argentina, where cinema has great relevance and close relationship with literature.

Like The Perón Novel, Saint Evita also presents both montage references but the discursive one is more frequent and has more weight to the novel's global message. This time there is no main event to string together the many narrative branches of the novel. The only common point they have is Evita. Nevertheless, the novel strives to convince the reader that she cannot be seen as a single historical figure but as a multiple dreamed symbol. The different narrative threads belong to incompatibles reality levels what can be seen in three scarce examples: 1. the metafictional narrative of the author's writing process that cannot actually meet; 2 . the adventures of Evita's embalmed body and neither; 3 . her life 
path towards fame and power. The connections of these three narrative threads are made by other narrative tracks like, e.g. the detective story of Colonel Moori Koenig, split into other narrative branches such as the investigation of Evita's life, the secret destiny of her unburied body and his widow interview conducted by the writer. The Moori Koenig plot is a contrastive, and therefore, a conflictive link to other narrative branches. All that shows a discursive montage through a juxtaposition system made in literary terms. Noteworthy in this novel is the radical kind of discursive montage employed.

The guiding principle of radical discursive montage is contrast and, hence, difference within no previous identified continuity. The image sequence must put together elements that are not usually associated in order to trigger off a perceptive process of potential meanings. The edit images should not be realized as a logical chain, but as a metaphorical concatenation. The arranged proximity reshapes the conventional meanings and brings critical thinking ${ }^{11}$. The discursive montage in Saint Evita is therefore less technical than in The Perón Novel, whose discursive devices are still indirectly related to continuity. The cinematic reference is applied here to put side by side not images as if they were film shots, but to link the narrative branches connecting metaphorically various story passages. A brief example of this can be seen with Colonel Moori alcoholism, firstly reveled to the novel's author by the Argentinian writer named Rodolfo Walsh as a biographical element inside his short story named Esa mujer, after described as a consequence of a family problem by the Colonel's wife within the adventures of Evita's embalmed body and finally characterized as a result of the deception Colonel was victim, inside his own detective story branch. The same element - Moori's alcoholism - develops different possible meanings due to the juxtaposition to other story passages - the biography details, the familiar drama and the detective persecution - within other narrative branches and it is up to the reader to notice them and work on their interpretation. The general suggestion of all these discursive montages is of an unstable history about Evita with no certainty and therefore no unquestionable truth.

Although less relevant, some narrative montage can also be found in Saint Evita through episode repetition, factual recurrence and same subject or same expression incidence spread throughout the novel. Evita's most known photograph is an example of that. Inside many of the narrative branches her iconic image with blond hair tied in a bun works as a match cut. It is shown at first in the testimony of a colleague from the time Evita was a poor brunette country girl trying to survive as an actress in Buenos Aires. Later, the image is back in the context of the writer's research on stories of Evita fans in old newspapers (poor girls in the countryside copying her hairstyle). Further on, still in the writer's narrative branch, it is mentioned as a sign of social distinction adopted by the upper classes. It is also brought up in the long story of Alcaraz, Evita's hairstylist (the creator of her blond style), and also in the embalmer's report. The frightening story of major Arancibia's obsession with Evita's dead body points it out too. At last, inside an intertextual level, it is there again in the referred short stories of Cortázar, El examen, and of Borges, El simulacro. The match cuts on

11 In order to explain this kind of discursive montage, Amiel (2010) proposes a direct relation of its effect to the figures of speech. An example of the metaphoric process is the result of the juxtaposition made in the beginning of Chaplin's Modern Times: a shot of workers walking follows a sheep herd moving ahead to suggest the ruthless way the workers are treated (AMIEL, 2005, p. 81). 
Evita's blond hair image, however, point out to a similarity that emphasizes multiplicity: each time it comes over, a new context gives it a different meaning. Saint Evita narrative montage devices as such are similar to the ones in The Perón Novel, but as binding points, they articulate incompatible fictional dimensions. Therefore, the overall result is more of divergence and openness than wholeness and closure.

\section{Conclusions}

Reshaping culture, a medium itself is reshaped and pushes more reshaping process. Cinema evolution and its social echoes must be considered in literary comparative studies in order to understand the cinematic intermedial references used in novels at different times. Since cinema became popular, a new way of writing stories is made possible through intermedial references. From the beginning of the $20^{\text {th }}$ century until now the way literature has been reshaped by the incorporation of film language has also evolved.

In the Argentinian context, literature and cinema have always had a close relationship and it is especially true in the case of Tomás Eloy Martinez. Since the eighties, the cinematic references in his work have been used to express a decentered fictional world. Their use gradually generated a more opened fictional world, with multiple conflictive points of view. First through intense narrative montage and a bit of discursive montage - as seen in The Perón Novel - and after, inverting the highlighted intermedial reference, a more intense discursive montage than a narrative one - as showed in Saint Evita. As a contemporary work, Martínez's novels illustrate cinematic features of literature in our time. Film reference works as a way to make literature speak the language of our time. A way to better communicate with a reader used to frequent visual messages with frenetic and sophisticate montage devices. The use of montage effects, especially through the emphasis in discursive montage, leaves to the reader a good amount of inferential work to do, building symbolic and unstable messages. Contemporary film devices give literature the opportunity to express an outline of our postmodern age: the loss of faith in any unifying and legitimating power of the grand narratives of truth or of any unequivocal certainty, as proposed by Lyotard (1986). A meaning openness and a general relativization process are typical modes of the postmodern Zeitgeist and they find a good way of expression through montage procedures.

It is noteworthy that the use of cinematic devices in literature, as seen here, does not match any goal of film language devices in cinema itself (it would be hard to assert the existence of decentered films in the same way). An intermedial reference as seen here means literary language working "as if" it was film language but still being literary language per se.

\section{NARRATIVA FÍLMICA NA LITERATURA CONTEMPORÂNEA: UM EXEMPLO ARGENTINO}

Resumo: Este artigo investiga a presença da linguagem cinematográfica em ficções contemporâneas através do exemplo de dois romances do escritor argentino Tomás Eloy Martínez: La novela de Perón (1985) e Santa Evita (1995). Diferente da maioria dos trabalhos a respeito de relações entre literatura e cinema, toma o diálogo intermidiático no sentido contrário - do filme para o livro - a fim 
de observar as configurações midiáticas aí em jogo em seus atributos intermidiáticos específicos. Discute também as relações históricas entre literatura e cinema para, dentro delas, examinar o modo como essa produção hispânica incorpora certos recursos filmicos.

Palavras-chave: Intermidialidade. Tomás Eloy Martínez. Montagem.

\section{REFERENCES}

AMIEL, V. Estética da montagem. Lisboa: Edições texto \& grafia, 2010.

BALAZS, B. Béla Balázs: early film theory (Visible Man and The Spirit of Film). New York: Berghahn Books, 2011.

BORDWELL, D.; THOMPSON, K. A arte do cinema: uma introdução. São Paulo: Edusp, 2014.

ECO, U. Pós-escrito a O nome da rosa. Rio de Janeiro: Nova Fronteira, 1985.

EISENSTEIN, S. Film form: essays in film theory. New York; London: A Harvest; HBJ Book, 1977.

LYOTARD, J.-F. O Pós-moderno. Rio de Janeiro: José Olympio, 1986.

MARTÍnEZ, T. E. La novela de Perón. Buenos Aires: Legasa, 1985.

MARTÍnEZ, T. E. Santa Evita. Buenos Aires: Planeta, 1995.

MCLUHAN, M. Os meios de comunicação como extensões do homem. São Paulo: Cultrix, 1979.

RAJEWSKY, I. Intermediality, intertextuality, and remediation: a literary perspective on intermediality. Intermédialités. Histoire et théorie des arts, des lettres et des techniques, Montreal, n. 6, p. 43-64, Fall 2005.

RAJEWSKY, I. Border Talks: the problematic status of media borders in the current debate about intermediality. In: ELLESTROM, L. (Ed.). Media borders, multimodality and intermediality. Hampshire: Palgrave Macmillan, 2010. p. 51-68.

RODRÍGUEZ MONEGAL, E. El Boom de la novela latinoamericana. Caracas: Tiempo Nuevo, 1972.

Recebido em novembro de 2016.

Aprovado em janeiro de 2017. 